\title{
Corticotropin Releasing Hormone Type 2 Receptors in the Dorsal Raphe Nucleus Mediate the Behavioral Consequences of Uncontrollable Stress
}

\author{
Sayamwong E. Hammack, ${ }^{1}$ Megan J. Schmid, ${ }^{2}$ Matthew L. LoPresti, ${ }^{2}$ Andre Der-Avakian, ${ }^{2}$ Mary Ann Pellymounter, ${ }^{3}$ \\ Alan C. Foster, ${ }^{3}$ Linda R. Watkins, ${ }^{2}$ and Steven F. Maier ${ }^{2}$ \\ ${ }^{1}$ Department of Psychiatry and Center for Behavioral Neuroscience, Emory University, Atlanta, Georgia 30322, ${ }^{2}$ Department of Psychology and Center for \\ Neuroscience, University of Colorado at Boulder, Boulder, Colorado 80309-0345, and ${ }^{3}$ Neurocrine Biosciences, San Diego, California 92121
}

Uncontrollable shock produces a constellation of behavioral changes that are not observed after equivalent escapable shock. These include interference with escape and potentiation of fear conditioning. The activation of corticotropin-releasing hormone (CRH) receptors within the caudal dorsal raphe nucleus (DRN) during inescapable tailshock (IS) has been shown to be critical for the development of these behavioral changes. CRH binds to two receptor subtypes, both of which are found in the DRN. The present set of studies examined which CRH receptor subtype mediates the effects of IS. Intra-DRN administration of the $\mathrm{CRH}_{2}$ receptor antagonist anti-sauvagine-30 before IS dose-dependently blocked IS-induced behavioral changes; the $\mathrm{CRH}_{1}$ receptor antagonist 2-methyl-4-( $\mathrm{N}$-propyl- $\mathrm{N}$-cycloproanemethylamino)-5-chloro-6-(2,4,6-trichloranilino)pyrimidine (NBI27914), administered in the same manner, did not. Moreover, the highly selective $\mathrm{CRH}_{2}$ receptor agonist urocortin II (Ucn II) dose-dependently caused behavioral changes associated with IS in the absence of shock. Ucn II was effective at doses 100-fold lower than those previously required for CRH. The relationship between $\mathrm{CRH}_{2}$ receptors and DRN 5-HT is discussed.

Key words: corticotropin releasing hormone; corticotropin releasing hormone receptor; dorsal raphe nucleus; learned helplessness; serotonin; urocortin II

\section{Introduction}

Situations in which organisms have no behavioral control over stressors produce a constellation of physiological and behavioral changes that do not occur if the stressor can be controlled, a phenomenon that has been called behavioral depression (Weiss et al., 1981) and learned helplessness (Maier and Seligman, 1976). When induced in animals, it includes many symptoms that overlap with depression and anxiety disorders (Porsolt et al., 1978; Sherman et al., 1979; Maier, 1984).

A variety of neural structures and transmitters are involved in the mediation of learned helplessness (Weiss et al., 1981; Maier et al., 1993). However, our laboratory has recently focused on changes in serotonergic (5-HT) neurons in the dorsal raphe nucleus (DRN) as a key element. Uncontrollable stress [inescapable tailshock (IS)], relative to controllable stress (escapable tailshock), differentially activates 5-HT cells in the caudal DRN (Grahn et al., 1999b) and leads to large amounts of extracellular 5-HT within the DRN and its projection regions (Amat et al., 1998a,b; Maswood et al., 1998). These changes in DRN 5-HT have been shown to be critical to the production of learned helplessness (Maier et al., 1994, 1995a,b). The DRN is likely to receive a variety of inputs during uncontrollable stress, and a number

\footnotetext{
Received July 15, 2002; revised 0ct. 24, 2002; accepted Nov. 8, 2002.

This work was supported by National Institutes of Health Grants MH50479 and DA13159 (S.F.M.) and by the Undergraduate Research Opportunities Program at the University of Colorado at Boulder.

Correspondence should be addressed to Dr. Sayamwong E. Hammack, Emory University, Department of Psychiatry Room 4000, 1639 Pierce Drive, Atlanta, GA 30322. E-mail: jom@psych.colorado.edu.

Copyright $\odot 2003$ Society for Neuroscience $\quad 0270-6474 / 03 / 231019-07 \$ 15.00 / 0$
}

have been delineated (Grahn et al., 1999a,c, 2000; Amat et al., 2001; Hammack et al., 2002). Corticotropin-releasing hormone $(\mathrm{CRH})$ is particularly interesting in this regard.

$\mathrm{CRH}$ is a 41 residue polypeptide that plays a key role in integrating the endocrine (Vale et al., 1981), autonomic (Brown and Fisher, 1985), and behavioral (Koob et al., 1993) responses to stress. An involvement of CRH in the mediation of learned helplessness was first suggested by Ronan et al. (2000), who found that the intracerebroventricular administration of a large dose of $\mathrm{CRH}$ produced failure to learn to escape footshock $24 \mathrm{hr}$ later, just as does IS. These findings were extended by Hammack et al. (2002), who found that DRN microinjection of a nonselective $\mathrm{CRH}$ antagonist before IS blocked the behavioral changes normally produced by IS, and that intra-DRN administration of $\mathrm{CRH}$ by itself produced IS-like behavioral changes $24 \mathrm{hr}$ later. Furthermore, these effects were quite selective and were restricted to microinjection into the caudal DRN.

$\mathrm{CRH}$ and $\mathrm{CRH}$-related peptides exert their biological activity by binding to two CRH receptor subtypes (DeSouza et al., 1985; Chalmers et al., 1995). The $\mathrm{CRH}_{1}$ receptor is widely distributed throughout the CNS (Van Pett et al., 2000), whereas the $\mathrm{CRH}_{2}$ receptor has a more limited distribution, primarily to subcortical regions (Chalmers et al., 1995). In addition, the two subtypes display quite different pharmacological profiles.

The study by Hammack et al. (2002) did not address the CRH receptor subtype within the DRN that mediates the effects of IS. The DRN contains an unusually high density of $\mathrm{CRH}_{2}$ receptors, as well as $\mathrm{CRH}_{1}$ receptors (Chalmers et al., 1995). The purpose of the reported experiments was to explore $\mathrm{CRH}_{1}$ and $\mathrm{CRH}_{2}$ recep- 
tor involvement in the DRN in the mediation of learned helplessness. The experiments determined whether (1) learned helplessness could be blocked by the intra-DRN microinjection of selective $\mathrm{CRH}_{1}(\mathrm{NBI} 27914)$ and $\mathrm{CRH}_{2}$ [anti-sauvagine-30 (ASV30)] antagonists, and (2) whether learned helplessness could be induced by intra-DRN administration of the highly selective $\mathrm{CRH}_{2}$ ligand urocortin II (Ucn II).

\section{Materials and Methods \\ Animals}

Male Sprague Dawley rats (Harlan Labs, Madison, WI) weighing 275325 gm were used in all experiments. Rats were housed singly and maintained on a $12 \mathrm{hr}$ light/dark cycle. Food and water were available ad libitum. Behavioral testing was performed between 8:00 A.M. and 12:00 P.M. All procedures were approved by the Institutional Animal Care and Use Committee of the University of Colorado at Boulder.

\section{Apparatus}

Rats given IS were placed into $17.5 \times 7.0 \mathrm{~cm}$ Plexiglas tubes. The rat's tail extended from the rear of the tube and was attached with tape to a Plexiglas rod. Electrodes were fixed to the tail, and computer-controlled $1.0 \mathrm{~mA}$ shocks were created by shock sources modeled after the GrasonStadler Model 700 shock source (Grason-Stadler Inc., Madison, WI).

For behavioral testing, rats were placed into shuttleboxes measuring $46 \times 20.7 \times 20 \mathrm{~cm}$. Scrambled $0.5 \mathrm{~mA}$ footshocks were delivered through stainless-steel grids on the floor of the apparatus. The shuttlebox was divided into halves by an aluminum wall containing an archway that allowed passage from one side to the other.

For locomotor activity, rats were placed in $30 \times 30 \times 30 \mathrm{~cm}$ Plexiglas boxes with walls that were striped with alternating 0.75 inch black and white electrical tape. The floor of each box was sanded Plexiglas covered with a wire mesh. A cable tie was loosely collared around the rat's neck, and a $2.0 \times 2.5 \mathrm{~cm}$ piece of reflective tape was attached to the cable tie. This occurred the day before behavioral testing. The reflective tape was tracked by a CCD camera (Philips Inc., Lancaster, PA) mounted $1.5 \mathrm{~m}$ above the testing apparatus. The camera was connected to a computer, and data were collected via Chromotrack tracking software (Prototype Systems Ltd., Boulder, CO).

\section{Surgery: cannulations}

Rats were anesthetized with Halothane (Halocarbon Laboratories, River Edge, NJ) and implanted with guide cannulas into the region of the DRN or into the region of the central nucleus of the amygdala (CeA). Twentysix gauge stainless-steel cannulas $13 \mathrm{~mm}$ long were implanted stereotaxically based on coordinates from the atlas of Paxinos and Watson (1986) and aimed $1.0 \mathrm{~mm}$ dorsal to the target region of the DRN or $3.0 \mathrm{~mm}$ dorsal to the area of the CeA to prevent damage to the areas. The bite bar was set at $-3.5 \mathrm{~mm}$, and the angle of approach was $0^{\circ}$ (straight down). Coordinates $1.0 \mathrm{~mm}$ dorsal to the DRN were as follows: anteroposterior (AP), $+1.0 \mathrm{~mm}$; dorsoventral (DV), $+4.3 \mathrm{~mm}$; and mediolateral (ML), 0 $\mathrm{mm}$, using interaural zero as a reference. Coordinates $3.0 \mathrm{~mm}$ dorsal to the CeA were as follows: AP, $-2.5 \mathrm{~mm}$; DV,$-5.2 \mathrm{~mm}$; and $\mathrm{ML}, \pm 4.2$ $\mathrm{mm}$, using the bregma as a reference.

\section{Procedure}

DRN NBI27914. One week after DRN cannulation, rats were randomly assigned to one of eight groups: IS plus $1.0 \mathrm{nmol}$ of NBI27914, IS plus 0.5 $\mathrm{nmol}$ of NBI27914, IS plus $0.1 \mathrm{nmol}$ of NBI27914, IS plus vehicle, home cage plus 1.0 of nmol NBI27914, home cage plus $0.5 \mathrm{nmol}$ of NBI27914, home cage plus $0.1 \mathrm{nmol}$ of NBI27914, or home cage plus vehicle. Thus, the design was a 2 (IS vs home-cage control) $\times 4$ (drug dose) factorial. Each rat was handheld in a towel during the injection procedure. The stylet was removed, and rats were hand-injected through the guide cannula with the $\mathrm{CRH}_{1}$ receptor antagonist NBI27914 (provided by Neurocrine Biosciences, San Diego, CA) or equivolume ( $0.5 \mu \mathrm{l})$ distilled water vehicle. The injector extended $1 \mathrm{~mm}$ below the end of the guide cannula into the DRN. Injectors were constructed of 33 gauge stainless-steel tubing (Small Parts Inc., Miami Lakes, FL) that was connected to a $50 \mu \mathrm{l}$ Hamilton syringe with a length of polyethylene-20 tubing. The flow of

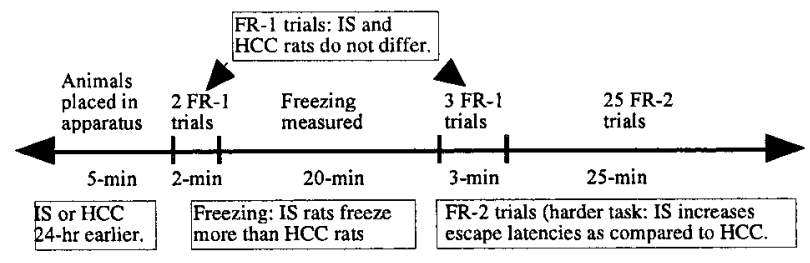

Figure 1. Procedure for measuring escape and fear behavior in the same subject.

drug was measured with a small air bubble created in the tubing. Injectors were left in place for $2 \mathrm{~min}$ to allow drug diffusion into brain tissue.

Fifteen minutes after the injection, IS rats were given $1005 \mathrm{sec}$ tailshocks delivered on a 1 min variable-interval schedule. Home-cage rats were returned to their home cages after injection.

All subjects received behavioral testing $24 \mathrm{hr}$ later. Both conditioned fear and shuttlebox escape learning were tested using a procedure described in detail previously (Maier et al., 1993). Freezing was measured for the first 5 min after placement in a shuttlebox. Each subject's behavior was scored every $8 \mathrm{sec}$ as being either freezing or not freezing. Freezing was defined as the absence of all movement except that required for respiration. The observer was blind with regard to treatment condition, and inter-rater reliability has been calculated to be $>0.92$.

This observation period was followed by two footshocks, which could be terminated by crossing to the other side of the shuttlebox [fixed ratio-1 (FR-1) trials]. IS does not alter FR-1 shuttlebox escape latencies (Maier et al., 1993); therefore, IS and home-cage subjects are here exposed to shocks of equal duration. These two shocks were followed by a 20 min observation period in which freezing was scored. Previous work has indicated that this freezing is a measure of fear that has been conditioned to the contextual cues of the shuttlebox (Fanselow and Lester, 1988). This observation period was followed by three additional FR-1 escape trials and then 25 FR-2 escape trials. The subjects were required to cross to the other side and then back to terminate shock on the FR-2 trials, and it is here that IS-induced escape deficits are typically revealed. Each shock terminated after $30 \mathrm{sec}$ if an escape response had not occurred. The testing procedure is schematized in Figure 1.

CeA NBI27914. To determine whether $1.0 \mathrm{nmol}$ of NBI27914 was effective in our laboratory, $1.0 \mathrm{nmol}$ of NBI27914 was injected into the CeA ( $0.5 \mathrm{nmol}$ per side) immediately before fear conditioning in the shuttlebox as a positive control. One week after CeA cannulation, rats were injected with either NBI27914 or equivolume vehicle and placed in the shuttlebox. Rats subsequently received two FR-1 trials and were scored for freezing as described above.

DRN ASV-30. One week after DRN cannulation, rats were randomly assigned to one of eight groups: IS plus $1.0 \mathrm{nmol}$ of ASV-30, IS plus 0.5 $\mathrm{nmol}$ of ASV-30, IS plus $0.1 \mathrm{nmol}$ of ASV-30, IS plus saline vehicle, home cage plus $1.0 \mathrm{nmol}$ of ASV-30, home cage plus $0.5 \mathrm{nmol}$ of ASV-30, home cage plus $0.1 \mathrm{nmol}$ of ASV-30, or home cage plus saline vehicle. Thus, the design here was also a 2 (IS vs home cage control) $\times 4$ (drug dose) factorial. After injection, all procedures were identical to those described for the NBI27914 experiment.

DRN Ucn II. One week after DRN cannulation, rats were microinjected with $0.5 \mu$ l of either $0.021,0.0021$, or $0.00021 \mathrm{nmol}(87,8.7$, or 0.87 $\mathrm{ng}$, respectively) of Ucn II or saline vehicle. Immediately after injection, rats were placed into separate plastic bins in a different room from their home cages for $2 \mathrm{hr}$. Rats were then returned to their home cages. Twenty-four hours later, rats were behaviorally tested for conditioned fear and shuttlebox escape performance as described above.

DRN Ucn II and locomotor behavior. One week after DRN cannulation, rats were microinjected with $0.5 \mu$ lof either $0.021 \mathrm{nmol}$ ( $87 \mathrm{ng}$ ) of Ucn II or saline vehicle. Immediately after injection, rats were placed into separate plastic bins in a different room from their home cages for $2 \mathrm{hr}$. Rats were then fitted with a homemade collar that contained a $2 \times 2 \mathrm{~cm}$ surface made of reflective tape that was oriented dorsally. The collars were fitted securely but without causing obvious discomfort. Rats were then returned to their home cages. Twenty-four hours after injection, rats were placed in the testing boxes for $50 \mathrm{~min}$ to assess locomotor behavior, which was tracked by the computer software. 

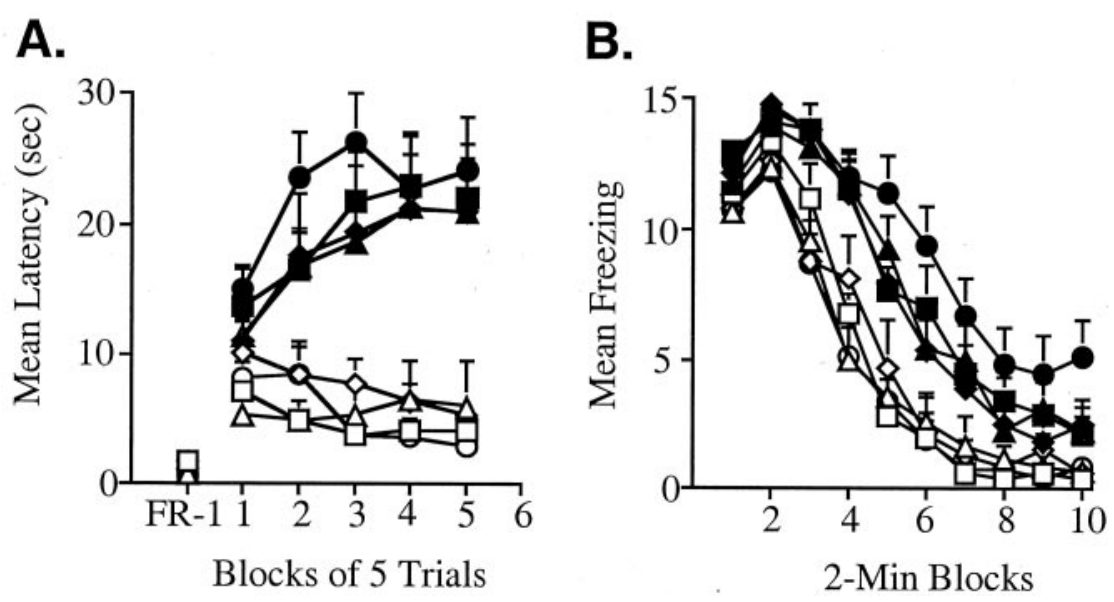

Figure 2. A, Mean shuttlebox escape latencies for FR-1 trials and five blocks of FR-2 trials. Rats either received IS or were left in their home cages $24 \mathrm{hr}$ previously. Rats also received an intra-DRN injection of $0.1,0.5$, or $1.0 \mathrm{nmol}$ of the $\mathrm{CRH}_{1}$ receptor antagonist NBI27914 or vehicle 15 min before IS treatment. $B$, Mean number of 8 sec periods in which freezing occurred across 2 min blocks, after two shocks in a shuttlebox. Rats either received IS or were left in their home cages $24 \mathrm{hr}$ previously. Rats also received an intra-DRN injection of $0.1,0.5$, or $1.0 \mathrm{nmol}$ of the $\mathrm{CRH}_{1}$ receptor antagonist NBI27914 or vehicle $15 \mathrm{~min}$ before IS treatment. Open squares, Home cage plus vehicle; open triangles, home cage plus $0.1 \mathrm{nmol}$ of NBI27914; open diamonds, home cage plus $0.5 \mathrm{nmol}$ of NBI27914; open circles, home cage plus $1 \mathrm{nmol}$ of NBI27914; filled squares, IS plus vehicle; filled triangles, IS plus $0.1 \mathrm{nmol}$ of NBI27914; filled diamonds, IS plus 0.5 nmol of NBI27914; filled circles, IS plus $1 \mathrm{nmol}$ of NBI27914.

\section{Histology}

To verify cannula placements, cannulated rats were anesthetized and injected through the guide cannula with Evans Blue dye $(1 \mu \mathrm{l})$. Rats were perfused after $15 \mathrm{~min}$ of dye diffusion, and their brains were removed and fixed in a $10 \%$ formalin and $30 \%$ sucrose solution. Brains were then sectioned on a cryostat and stained with cresyl violet. Cannula verifications of the sections were conducted under a light microscope.

\section{Statistical analysis}

Data were analyzed with repeated-measures ANOVA and followed with a Newman-Keuls analysis ( $\alpha$ set at 0.05 ), which made all possible pairwise comparisons.

\section{Results}

\section{DRN NBI27914}

Injecting the $\mathrm{CRH}_{1}$ receptor antagonist NBI27914 into the DRN before IS did not alter the interference with FR-2 escape responding (Fig. 2A) or potentiated fear conditioning (Fig. $2 B$ ) normally observed $24 \mathrm{hr}$ later at any dose tested. For FR-2 escape latencies, there was an effect of group $\left(F_{(7,47)}=8.104 ; p<0.05\right)$, an effect of trials $\left(F_{(4,188)}=6.157 ; p<0.05\right)$, and a significant interaction between group and FR-2 trials $\left(F_{(28,188)}=3.782 ; p<0.05\right)$. These significant effects indicated that IS increased escape latencies above home-cage treatment. Newman-Keuls analysis revealed that there was no effect of any dose of NBI27914. All IS groups differed from all home-cage groups, but IS groups administered each dose of NBI27914 did not differ from IS groups administered vehicle, nor did they differ from each other. Moreover, there was no effect of NBI27914 in home-cage rats, because there were no significant differences between home-cage rats given any dose of NBI27914 or vehicle. For freezing behavior, there was a significant effect of group $\left(F_{(7,45)}=7.042 ; p<0.05\right)$, a significant effect of 2 min blocks $\left(F_{(9,405)}=305.089 ; p<0.05\right)$, and a significant interaction between group and 2 min blocks $\left(F_{(63,405)}=\right.$ 7.644; $p<0.05)$. Again, these significant effects indicated that IS potentiated freezing above home-cage treatment; however, Newman-Keuls analyses revealed that there was no effect of any dose of NBI27914. All IS groups differed from all home-cage groups, but IS groups administered each dose of NBI27914 did not differ from IS groups administered vehicle, nor did they differ from each other. Moreover, there was no effect of NBI27914 in homecage rats, because there were no significant differences between home-cage rats given any dose of NBI27914 or vehicle.

\section{CeA NBI27914}

Cannula placements for rats injected with NBI27914 into the CeA are shown in Figure 3. Injecting the $\mathrm{CRH}_{1}$ receptor antagonist NBI27914 into the CeA before fear conditioning suppressed freezing behavior measured after two shocks in a shuttlebox (Fig. 4). There was an effect of drug treatment $\left(F_{(1,10)}=18.823 ; p<0.05\right)$, an effect across the 102 min blocks of freezing $\left(F_{(9,90)}=18.851 ; p<0.05\right)$, and an interaction between drug treatment and $2 \mathrm{~min}$ blocks of freezing $\left(F_{(9,90)}=2.282 ; p<\right.$ $0.05)$.

\section{DRN ASV-30}

Cannula placements for rats injected with $1 \mathrm{nmol}$ of ASV-30 into the DRN are shown in Figure 5. Injecting the $\mathrm{CRH}_{2}$ receptor antagonist ASV-30 into the DRN before IS dose-dependently blocked the interference with FR-2 escape responding (Fig. 6A) and potentiated fear conditioning (Fig. $6 B$ ) normally observed 24 hr later. When ASV-30 was administered into the DRN before IS, the $0.5 \mathrm{nmol}$ dose suppressed, and the $1.0 \mathrm{nmol}$ dose blocked, the interference with escape responding normally observed $24 \mathrm{hr}$ later, and the same pattern was exhibited by freezing behavior. For FR-2 escape latencies, there was an effect of group $\left(F_{(7,50)}=\right.$ $10.910 ; p<0.05)$, an effect of trials $\left(F_{(4,200)}=2.387 ; p<0.05\right)$, and a significant interaction between group and FR-2 trials $\left(F_{(28,200)}=3.624 ; p<0.05\right)$. Newman-Keuls analyses revealed that there was a significant difference between the IS plus vehicle group and all IS groups receiving a dose of ASV-30. In addition,

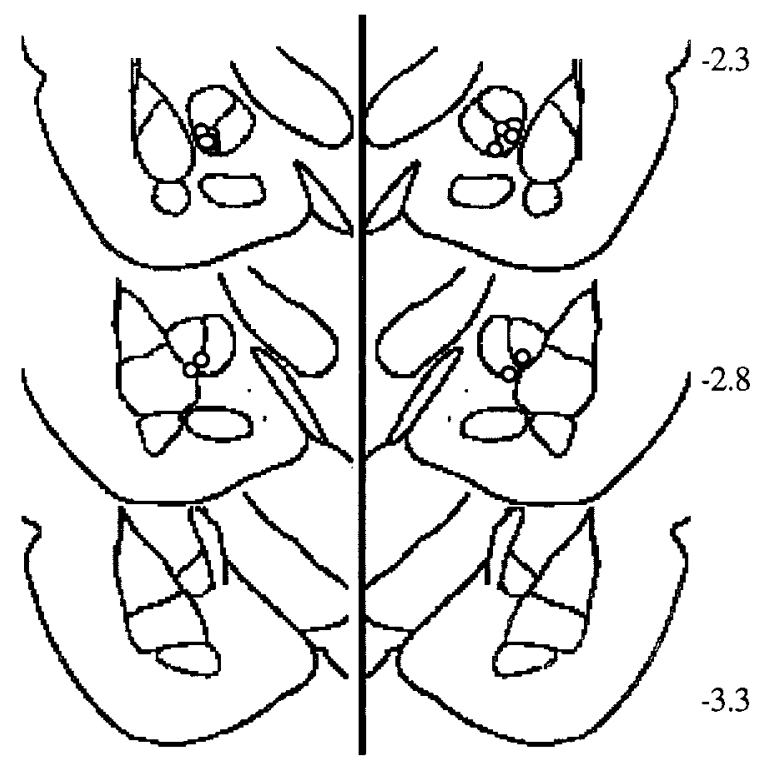

Figure 3. CeA injection placements for rats injected with $0.5 \mathrm{nmol}$ of NBI 27914 per side. Each circle represents the center of one dye injection. 


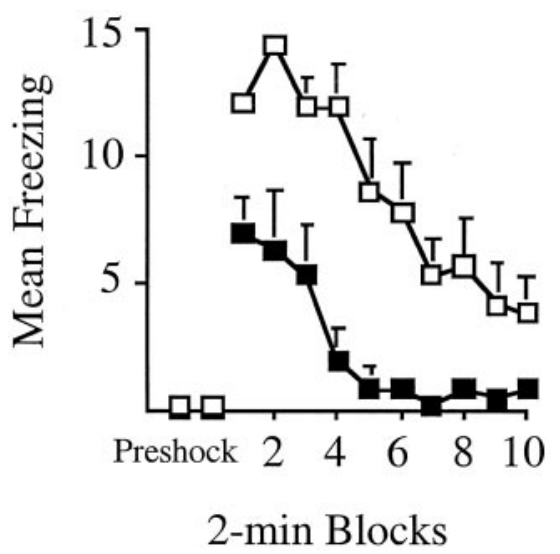

Figure 4. Mean number of 8 sec periods in which freezing occurred across 2 min blocks, after two shocks in a shuttlebox. Rats received $0.5 \mathrm{nmol}$ of NBI27914 per side or equivolume vehicle into the CeA 15 min before the two shocks. Although NBI27914 did not affect IS-induced behavioral changes when injected into the DRN, it suppressed fear conditioning when injected into the amygdala. Filled squares, NBI27914; open squares, vehicle.

the IS plus vehicle group differed significantly from all home-cage groups. The IS plus $0.1 \mathrm{nmol}$ of ASV group differed significantly from the IS plus $0.5 \mathrm{nmol}$ of ASV and IS plus $1.0 \mathrm{nmol}$ of ASV groups, and the latter two groups did not differ from each other or from any home-cage group. For freezing behavior, there was a significant effect of group $\left(F_{(7,50)}=11.683 ; p<0.05\right)$, a significant effect of 2 min blocks $\left(F_{(9,450)}=475.264 ; p<0.05\right)$, and a significant interaction between group and 2 min blocks $\left(F_{(63,450)}=6.836 ; p<\right.$ $0.05)$. Similarly, Newman-Keuls analysis revealed that there was a significant difference between the IS plus vehicle group and all IS groups receiving a dose of ASV-30 except for the $0.1 \mathrm{nmol}$ dose. In addition, the IS plus vehicle group significantly differed from all home-cage groups. The IS plus $0.1 \mathrm{nmol}$ of ASV group significantly differed from the IS plus $0.5 \mathrm{nmol}$ of ASV and IS plus $1.0 \mathrm{nmol}$ of ASV groups, and the latter two groups did not differ from each other or from any home-cage group.

\section{DRN Ucn II}

Ucn II injected into the caudal DRN dosedependently increased FR-2 escape latencies (Fig. 7A) and conditioned fear (Fig. $7 B) 24 \mathrm{hr}$ later. For FR-2 escape latencies, there was an effect of drug $\left(F_{(3,27)}=3.395\right.$; $p<0.05)$ and an interaction between drug and trials $\left(F_{(12,108)}=3.310 ; p<0.05\right)$. For freezing behavior, there was a reliable effect of drug $\left(F_{(3,26)}=13.771 ; p<0.05\right)$ and an interaction between drug and time $\left(F_{(27,234)}=2.158 ; p<0.05\right)$. The 0.021 nmol group was significantly different from all other groups.

\section{DRN Ucn II and locomotor behavior}

Ucn II injected into the caudal DRN did not affect locomotor behavior tested $24 \mathrm{hr}$ later (Fig. 8). There was not even a marginally significant effect of drug $\left(F_{(1,14)}=\right.$ $0.967 ; p>0.05)$. Although there was an effect of trials $\left(F_{(9,126)}=3.176 ; p<0.05\right)$, there was no interaction between drug and trials $\left(F_{(9,126)}=0.473 ; p>0.05\right)$.

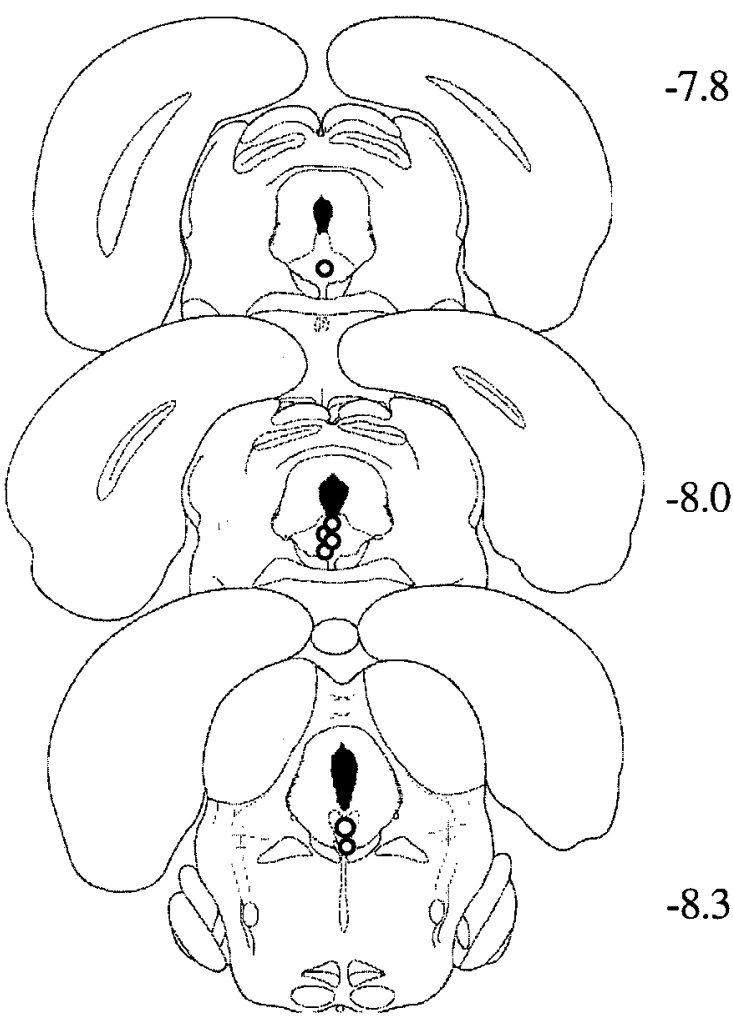

Figure 5. DRN injection placements for rats injected with $1 \mathrm{nmol}$ of anti-sauvagine-30. Each circle represents the center of one dye injection.

\section{Discussion}

The present results further support the notion that CRH (Ronan et al., 2000), and CRH within the DRN (Hammack et al., 2002), play a key role in mediating the behavioral consequences of uncontrollable stressors. It is unknown whether the CRH or another CRH-related peptide that is involved is intrinsic to the DRN or derives from projections to the DRN, but it can be noted that the
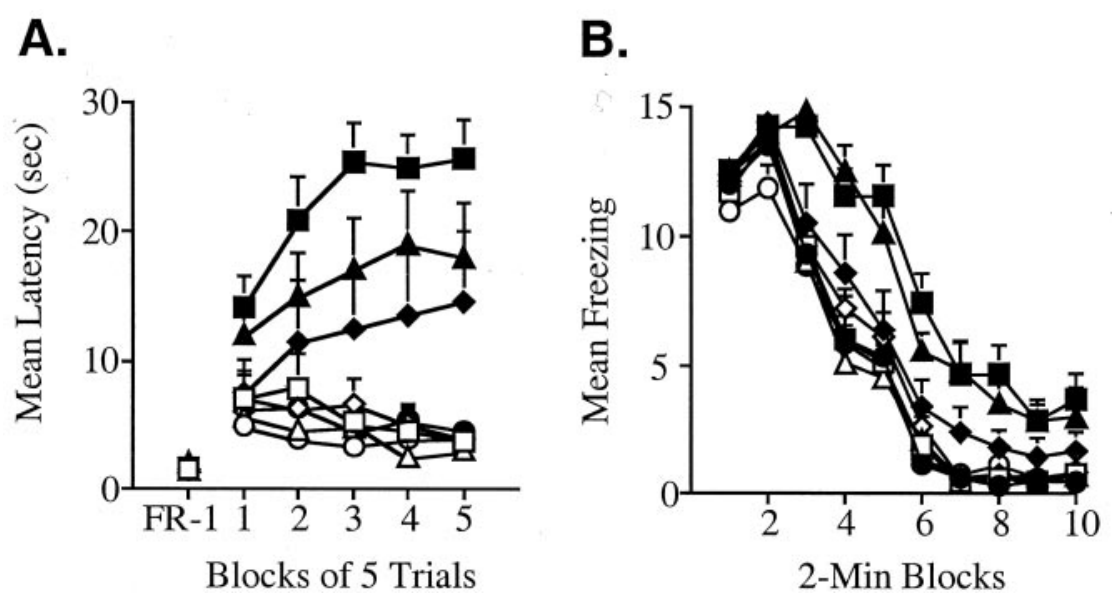

Figure 6. A, Mean shuttlebox escapelatencies for FR-1 trials and five blocks of FR-2 trials. Rats received either inescapable shock or were left in their home cages $24 \mathrm{hr}$ previously. Rats also received an intra-DRN injection of $0.1,0.5$, or $1.0 \mathrm{nmol}$ of the $\mathrm{CRH}_{2}$ receptor antagonist anti-sauvagine-30 or vehicle 15 min before $1 S$ treatment. $B$, Mean number of 8 sec periods in which freezing occurred across 2 min blocks, after two shocks in a shuttlebox. Rats received either inescapable shock or were left in their home cages $24 \mathrm{hr}$ previously. Rats also received an intra-DRN injection of $0.1,0.5$, or $1.0 \mathrm{nmol}$ of the $\mathrm{CRH}_{2}$ receptor antagonist anti-sauvagine-30 or vehicle 15 min before IS treatment. Open squares, Home cage plus vehicle; open triangles, home cage plus $0.1 \mathrm{nmol}$ of ASV-30; open triangles, home cage plus $0.5 \mathrm{nmol}$ of ASV-30; open circles, home cage plus $1 \mathrm{nmol}$ of ASV-30; filled squares, IS plus vehicle; filled triangles, IS plus $0.1 \mathrm{nmol}$ of ASV-30; filled diamonds, IS plus $0.5 \mathrm{nmol}$ of ASV-30; filled circles, IS plus $1 \mathrm{nmol}$ of ASV-30. 


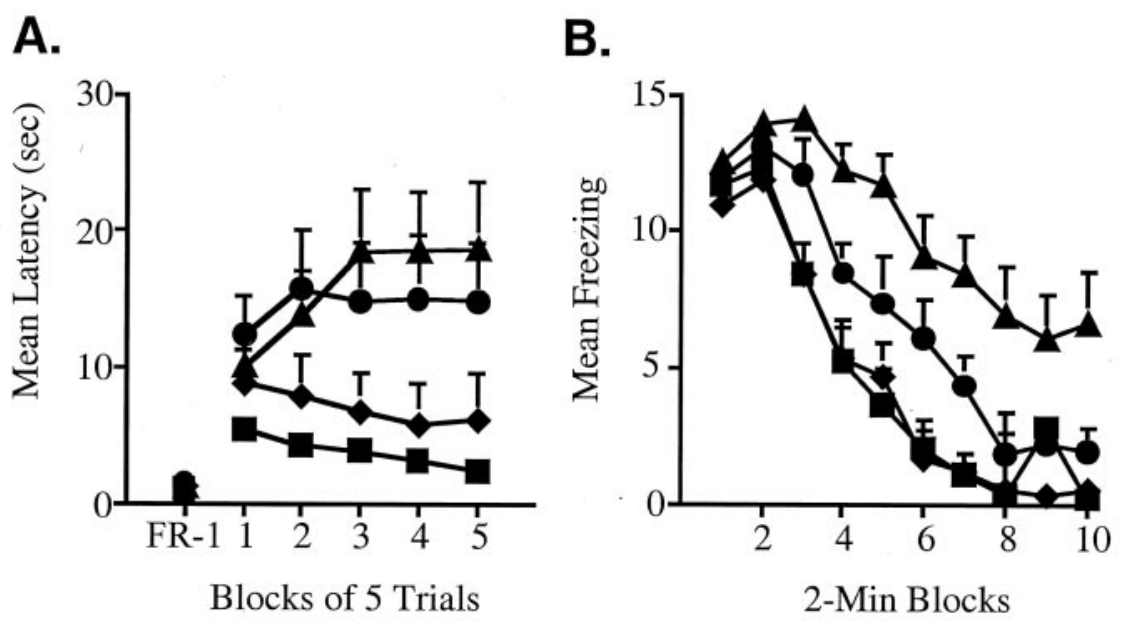

Figure 7. A, Mean shuttlebox escape latencies for FR-1 trials and five blocks of FR-2 trials. Rats either received $0.021 \mathrm{nmol}(87 \mathrm{ng})$, $0.0021 \mathrm{nmol}(8.7 \mathrm{ng})$, or $0.00021 \mathrm{nmol}(0.87 \mathrm{ng})$ of the $\mathrm{CRH}_{2}$ receptor agonist Ucn Il or saline vehicle into the DRN 24 hr previously. $B$, Mean number of 8 sec periods in which freezing occurred across 2 min blocks, after two shocks in the shuttlebox. Filled squares, Vehicle; filled diamonds, $0.00021 \mathrm{nmol}$ of Ucn II; filled circles, $0.0021 \mathrm{nmol}$ of Uen II; filled triangles, $0.021 \mathrm{nmol}$ of Ucn II.

DRN receives CRH projections from a variety of forebrain and limbic structures, including the amygdala and bed nucleus of the stria terminalis (Swanson et al., 1983; Sakanaka et al., 1986). In addition, the CRH-related peptides Ucn I (Bittencourt et al., 1999), Ucn II (Reyes et al., 2001), and Ucn III (Lewis et al., 2001) mRNAs are localized in regions that are known to project to the DRN. However, whether the projections from these regions to the DRN contain Ucn II or Ucn III is unknown.

Although the present data do not indicate the source of $\mathrm{CRH}$ or other CRH-related peptide involvement, they do suggest that DRN $\mathrm{CRH}_{2}$ receptors within the DRN mediate learned helplessness. ASV-30, which is 100 - to 1000 -fold selective for $\mathrm{CRH}_{2}$ (Higelin et al., 2001), dose-dependently blocked both the interference with escape learning and potentiation of fear conditioning produced by IS. The highly selective $\mathrm{CRH}_{1}$ antagonist NBI27914 (Chen et al., 1996) had no effect whatsoever at the same molar doses. Moreover, the NBI27914 doses were well within the effective range, given the intracerebroventricular doses that have been used (Baram et al., 1997; Martinez et al., 1998; Pelleymounter et al., 2000), and were effective in suppressing fear conditioning when injected into the CeA. Furthermore, the intra-DRN administration of Ucn II induced both poor escape learning and potentiation of fear conditioning $24 \mathrm{hr}$ later, just as does IS. Ucn II was effective at 100-1000 lower molar concentrations than required for $\mathrm{CRH}$ to produce these effects (Hammack et al., 2002), and Ucn II has been estimated to be 100 -fold more active at the $\mathrm{CRH}_{2}$ receptor than is $\mathrm{CRH}$ (Reyes et al., 2001). Importantly, Ucn II has little if any activity at the $\mathrm{CRH}_{1}$ receptor in either binding (Reyes et al., 2001) or cAMP production (Lewis et al., 2001) assays.

Although, Ucn II has been shown to suppress locomotor activity mildly (Valdez et al., 2002), there has been no indication that it would suppress activity $24 \mathrm{hr}$ later. Nevertheless, the present experiments assessed whether the dose of Ucn II used here would suppress motor activity $24 \mathrm{hr}$ later, and it did not. Therefore, the effects of Ucn II on shuttle escape $24 \mathrm{hr}$ later could not be attributed to a general decrease in locomotor activity.

The presence of high densities of $\mathrm{CRH}_{2}$ receptors within the DRN (Chalmers et al., 1995) is consistent with the possibility that $\mathrm{CRH}_{2}$ rather than $\mathrm{CRH}_{1}$ receptors within the DRN are critical in the production of learned helplessness. However, this conclusion might seem to be at odds with Mansbach et al. (1997) and Takamori et al. (2001), who reported that peripheral administration of $\mathrm{CRH}_{1}$-selective nonpeptide antagonists before IS reduced IS-induced escape failure. There are at least two possibilities. First, $\mathrm{CRH}_{1}$ receptors outside the DRN could also be involved in the mediation of the behavioral consequences of IS. Learned helplessness is mediated by a neural circuit that involves numerous structures and transmitters, with the DRN being only one, but perhaps a key, nodal point. Because the $\mathrm{CRH}_{1}$ receptor has a wide distribution, this receptor could be involved at other points in the circuit and the Mansbach et al. (1997) and Takamori et al. (2001) studies used systemic drug administration. Second, the behavioral procedures used by Mansbach et al. (1997) and Takamori et al. (2001) were qualitatively different from those used here. Indeed, Deak et al. (1999) showed that the $\mathrm{CRH}_{1}$-selective antagonist antalarmin did not block IS-induced escape failure using procedures identical to those presented here.

A predominant role within the DRN for the $\mathrm{CRH}_{2}$ receptor in the mediation of learned helplessness aids in the explanation of some aspects of the data concerning the effects of CRH within this paradigm. Both Ronan et al. (2000) and Hammack et al. (2002) found that very large doses of $\mathrm{CRH}$ were needed to mimic the usual effects of IS. Ronan et al. (2000) found that $10.0 \mu \mathrm{g}$ of intracerebroventricular $\mathrm{CRH}$ was required to produce escape failure $24 \mathrm{hr}$ later, whereas Hammack et al. (2001) reported that two doses of $10.0 \mu \mathrm{g}$ of intracerebroventricular rat/human $(\mathrm{r} / \mathrm{h})$ $\mathrm{CRH}$ were required. In contrast, behavioral effects presumably mediated by $\mathrm{CRH}_{1}$ receptors have been produced using $\leq 1.0 \mu \mathrm{g}$ intracerebroventricularly (Lee and Davis, 1997). Consistent with the requirement of these large intracerebroventricular doses, Hammack et al. (2001) reported that the intra-DRN microinjec-

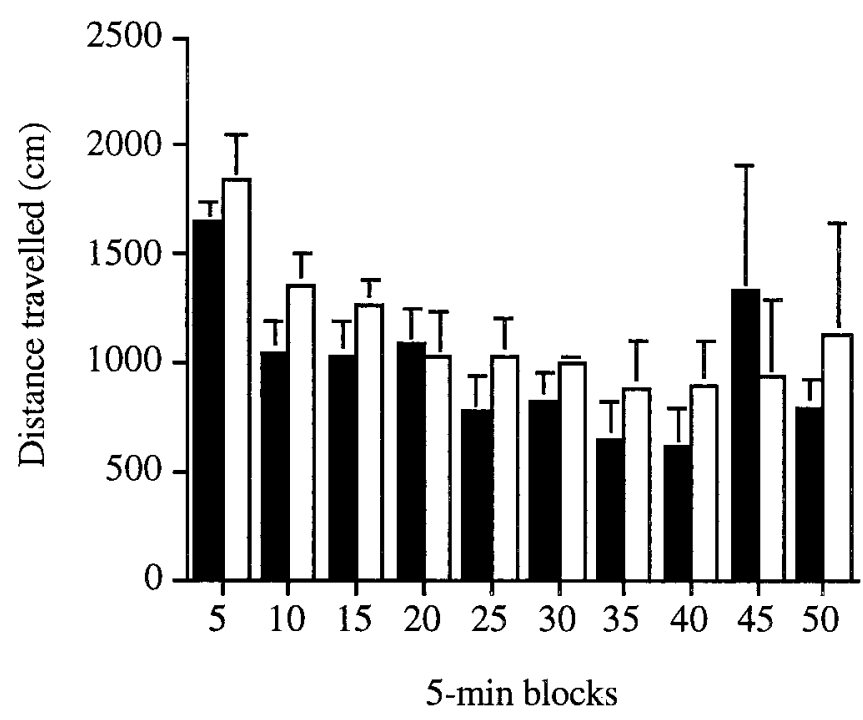

Figure 8. At $24 \mathrm{hr}$ after $0.021 \mathrm{nmol}(87 \mathrm{ng})$ of Ucn II or equivolume vehicle injection into the DRN, locomotor activity was scored in 5 min blocks for $50 \mathrm{~min}$. Ucn II injection did not reliably alter locomotor activity tested $24 \mathrm{hr}$ after injection. White columns, Ucn II; black columns, vehicle. 
tion of between 0.5 and $1.0 \mu \mathrm{g}$ of $\mathrm{r} / \mathrm{h} \mathrm{CRH}$ was needed to produce escape failures and potentiated fear conditioning $24 \mathrm{hr}$ later. As a comparison, intra-DRN doses of CRH in the 1.0-10.0 ng range inhibit DRN 5-HT electrical activity, a phenomenon likely mediated by $\mathrm{CRH}_{1}$ receptors in that it is blocked by antalarmin (Kirby et al., 2000). CRH binds preferentially to the $\mathrm{CRH}_{1}$ receptor (Lovenberg et al., 1995), and so $\mathrm{CRH}_{2}$ receptor mediation of learned helplessness would account for the large doses of CRH required to induce it. As noted above, much lower doses of Ucn II, which preferentially binds $\mathrm{CRH}_{2}$ receptors, were required. These data suggest that the endogenous ligand responsible for DRN $\mathrm{CRH}_{2}$ receptor activation during uncontrollable stress might not be $\mathrm{CRH}$, but rather a peptide more selective to the $\mathrm{CRH}_{2}$ receptor such as Ucn II or Ucn III.

The present data are also of potential relevance to an issue concerning whether CRH within the DRN excites or inhibits 5-HT neurons. Clearly, the implication here is that intra-DRN CRH mimics the behavioral effects of IS because it activates 5-HT neurons. This is because (1) IS does activate DRN 5-HT neurons (Maswood et al., 1998; Grahn et al., 1999b), (2) the behavioral effects of IS are mimicked by intra-DRN administration of other agents that do activate 5-HT neurons (Maier et al., 1995b; Grahn et al., 1999a), and (3) the intra-DRN administration of agents that inhibit 5-HT activity blocks the behavioral effects of IS (Maier et al., 1995a). However, low doses of intra-DRN and intracerebroventricular CRH have been reported to inhibit DRN 5-HT electrical activity (Price et al., 1998; Kirby et al., 2000) and 5-HT efflux in DRN projection regions (Price and Lucki, 2001). Interestingly, as the CRH dose was increased in these studies, the inhibitory effects decreased; with additional increases in dose, the effects of CRH tended to become excitatory. This pattern is consistent with the idea proposed by Kirby et al. (2000) that $\mathrm{CRH}_{1}$ receptors might mediate predominantly inhibitory effects on 5-HT neurons within the DRN, whereas $\mathrm{CRH}_{2}$ receptor activation leads to excitatory effects. Indeed, Price and Lucki (2001) reported that $\mathrm{r} / \mathrm{h} \mathrm{CRH}$ lacked inhibitory effects at the same dosages at which ovine $\mathrm{CRH}$ (oCRH) exerted strong inhibition. This is noteworthy because oCRH has a higher selectivity for the $\mathrm{CRH}_{1}$ receptor than does r/h CRH (Lovenberg et al., 1995).

The present data are consistent with other recent reports implicating the $\mathrm{CRH}_{2}$ receptor in the mediation of anxiety (Ho et al., 2001; Takahashi et al., 2001; Bakshi et al., 2002), although they are at odds with other reports suggesting an anxiolytic role for the $\mathrm{CRH}_{2}$ receptor (Bale et al., 2000, 2002; Kishimoto et al., 2000). These latter studies have shown that $\mathrm{CRH}_{2}$ receptor knock-out mice show increased levels of anxiety on several tests, suggesting an anxiolytic role for $\mathrm{CRH}_{2}$ receptors. However, the interpretation of such data are difficult because of the possibility that compensatory mechanisms may change the behavioral phenotype of the mature mice. Furthermore, in studies in which $\mathrm{CRH}_{2}$ receptors were inactivated by antagonists (Takahashi et al., 2001; Bakshi et al., 2002) or antisense oligonucleotides (Ho et al., 2001), anxiety-like behavior was generally suppressed, suggesting an anxiogenic role for the receptor. In any case, the present experiments address only the role of the $\mathrm{CRH}_{2}$ receptor in the DRN. This is a very different issue than the net effect of $\mathrm{CRH}_{2}$ receptor activation across the brain. The role of the $\mathrm{CRH}_{2}$ receptor in anxiety is likely complicated, and the site of action may be critical. For example, antagonism of $\mathrm{CRH}_{2}$ receptors in the lateral septum suppresses shock-induced freezing (Bakshi et al., 2002).

Exposure to uncontrollable, relative to controllable, stressors induces behavioral changes characteristic of anxiety (Short and Maier, 1993). The DRN and 5-HT projections from the DRN have been argued to be important in the production of anxiety (Graeff et al., 1996), and $\mathrm{CRH}_{2}$ receptors in this region may play an important role in the activation of these neurons during anxiety-arousing circumstances such as exposure to uncontrollable stressors.

\section{References}

Amat J, Matus-Amat P, Watkins LR, Maier SF (1998a) Escapable and inescapable stress differentially and selectively alter extracellular levels of 5-HT in the ventral hippocampus and dorsal periaqueductal gray of the rat. Brain Res 797:12-22.

Amat J, Matus-Amat P, Watkins LR, Maier SF (1998b) Escapable and inescapable stress differentially alter extracellular levels of 5-HT in the basolateral amygdala of the rat. Brain Res 812:113-120.

Amat J, Sparks PD, Matus-Amat P, Griggs J, Watkins LR, Maier SF (2001) The role of the habenular complex in the elevation of dorsal raphe nucleus serotonin and the changes in the behavioral responses produced by uncontrollable stress. Brain Res 917:118-126.

Bakshi VP, Smith-Roe S, Newman SM, Grigoriadis DE, Kalin NH (2002) Reduction of stress-induced behavior by antagonism of corticotropinreleasing hormone 2 (CRH2) receptors in lateral septum of CRH1 receptors in amygdala. J Neurosci 22:2926-2935.

Bale TL, Contarino A, Smith GW, Chan R, Gold LH, Sawchenko PE, Koob GF, Vale WW, Lee KF (2000) Mice deficient for corticotropin-releasing hormone receptor-2 display anxiety-like behavior and are hyper-sensitive to stress. Nat Genet 24:410-414.

Bale TL, Picetti R, Contarino A, Koob GF, Vale WW, Lee KF (2002) Mice deficient for both corticotropin-releasing factor receptor 1 (CRFR1) and CRFR2 have an impaired stress response and display sexually dichotomous anxiety-like behavior. J Neurosci 22:193-199.

Baram TZ, Chalmers DT, Chen C, Koutsoukos Y, De Souza EB (1997) The CRF1 receptor mediates the excitatory actions of corticotropin releasing factor (CRF) in the developing rat brain: in vivo evidence using a novel, selective, non-peptide CRF receptor antagonist. Brain Res 770:89-95.

Bittencourt JC, Vaughan J, Arias C, Rissman RA, Vale WW, Sawchenko PE (1999) Urocortin expression in rat brain: evidence against a pervasive relationship of urocortin-containing projections with targets bearing type 2 CRF receptors. J Comp Neurol 415:285-312.

Brown MR, Fisher LA (1985) Corticotropin-releasing factor: effects on the autonomic nervous system and visceral systems. Fed Proc 44:243-248.

Chalmers DT, Lovenberg TW, De Souza EB (1995) Localization of novel corticotropin-releasing factor receptor (CRF2) mRNA expression to specific subcortical nuclei in rat brain: comparison with CRF1 receptor mRNA expression. J Neurosci 15:6340-6350.

Chen C, Dagnino Jr R, De Souza EB, Grigoriadis DE, Huang CQ, Kim KI, Liu Z, Moran T, Webb TR, Whitten JP, Xie YF, McCarthy JR (1996) Design and synthesis of a series of non-peptide high-affinity human corticotropin-releasing factor 1 receptor antagonists. J Med Chem 39:4358-4360.

Deak T, Nguyen KT, Ehrlich AL, Watkins LR, Spencer RL, Maier SF, Licinio J, Wong ML, Chrousos GP, Webster E, Gold PW (1999) The impact of the nonpeptide corticotropin-releasing hormone antagonist antalarmin on behavioral and endocrine responses to stress. Endocrinology 140:79-86.

DeSouza EB, Insel TR, Perrin MH, Rivier J, Vale WW, Kuhar MJ (1985) Corticotropin-releasing factor receptors are widely distributed within the rat central nervous system: an autoradiographic study. J Neurosci 5:3189-3203.

Fanselow M, Lester L (1988) A functional behavioristic approach to aversively motivated behavior: predatory imminence as a determinant of the topography of defensive behavior. In: Evolution and learning (Bolles RC, Beecher MD, eds). Hillsdale, NJ: Erlbaum.

Graeff FG, Guimaraes FS, De Andrade TG, Deakin JF (1996) Role of 5-HT in stress, anxiety, and depression. Pharmacol Biochem Behav 54:129-141.

Grahn RE, Maswood S, McQueen MB, Watkins LR, Maier SF (1999a) Opioid-dependent effects of inescapable shock on escape behavior and conditioned fear responding are mediated by the dorsal raphe nucleus. Behav Brain Res 99:153-167.

Grahn RE, Will MJ, Hammack SE, Maswood S, McQueen MB, Watkins LR, Maier SF (1999b) Activation of serotonin-immunoreactive cells in the dorsal raphe nucleus in rats exposed to an uncontrollable stressor. Brain Res 826:35-43.

Grahn RE, Hammack SE, Will MJ, O’Connor KA, Deak T, Sparks PD, 
Watkins LR, Maier SF (1999c) The noradrenergic $\alpha$-1 antagonist benoxathian microinjected into the dorsal raphe nucleus prevents enhanced conditioned fear and escape failure produced by inescapable tailshock in rats. Soc Neurosci Abstr 25:76.

Grahn RE, Watkins LR, Maier SF (2000) Impaired escape performance and enhanced conditioned fear in rats following exposure to an uncontrollable stressor are mediated by glutamate and nitric oxide in the dorsal raphe nucleus. Behav Brain Res 112:33-41.

Hammack SE, Richey KJ, Schmid MJ, LoPresti ML, Watkins LR, Maier SF (2002) The role of corticotropin releasing hormone in the dorsal raphe nucleus in mediating the behavioral consequences of uncontrollable stress. J Neurosci 22:1020-1026.

Higelin J, Py-Lang G, Paternoster C, Ellis GJ, Patel A, Dautzenberg FM (2001) ${ }^{125}$ I-Antisauvagine-30: a novel and specific high-affinity radioligand for the characterization of corticotropin-releasing factor type 2 receptors. Neuropharmacology 40:114-122.

Ho SP, Takahashi LK, Livanov V, Spencer K, Lesher T, Maciag C, Smith MA, Rohrbach KW, Hartig PR, Arneric SP (2001) Attenuation of fear conditioning by antisense inhibition of brain corticotropin releasing factor-2 receptor. Brain Res Mol Brain Res 89:29-40.

Kirby LG, Rice KC, Valentino RJ (2000) Effects of corticotropin-releasing factor on neuronal activity in the serotonergic dorsal raphe nucleus. Neuropsychopharmacology [Erratum (2000) 22:449] 22:148-162.

Kishimoto T, Radulovic J, Radulovic M, Lin C, Schrick C, Hooshmand F, Hermanson O, Rosenfeld MG, Spiess J (2000) Deletion of Crhr2 reveals an anxiolytic role for corticotropin-releasing hormone receptor-2. Nat Genet 24:415-419.

Koob GF, Heinrichs SC, Pich EM, Menzaghi F, Baldwin H, Miczek K, Britton KT (1993) The role of corticotropin-releasing factor in behavioural responses to stress. Ciba Found Symp 172:277-289.

Lee Y, Davis M (1997) Role of the hippocampus, the bed nucleus of the stria terminalis, and the amygdala in the excitatory effect of corticotropinreleasing hormone on the acoustic startle reflex. J Neurosci 17:6434-6446.

Lewis K, Li C, Perrin MH, Blount A, Kunitake K, Donaldson C, Vaughan J, Reyes TM, Gulyas J, Fischer W, Bilezikjian L, Rivier J, Sawchenko PE, Vale WW (2001) Identification of urocortin III, an additional member of the corticotropin-releasing factor (CRF) family with high affinity for the CRF2 receptor. Proc Natl Acad Sci USA 98:7570-7575.

Lovenberg TW, Liaw CW, Grigoriadis DE, Clevenger W, Chalmers DT, De Souza EB, Oltersdorf T (1995) Cloning and characterization of a functionally distinct corticotropin-releasing factor receptor subtype from rat brain. Proc Natl Acad Sci USA 92:836-840.

Maier SF (1984) Learned helplessness and animal models of depression. Prog Neuropsychopharmacol Biol Psychiatry 8:435-446.

Maier SF, Seligman MEP (1976) Learned helplessness: theory and evidence. J Exp Psychol Gen 105:3-46.

Maier SF, Grahn RE, Kalman BA, Sutton LC, Wiertelak EP, Watkins LR (1993) The role of the amygdala and dorsal raphe nucleus in mediating the behavioral consequences of inescapable shock. Behav Neurosci 107:377-388.

Maier SF, Kalman BA, Grahn RE (1994) Chlordiazepoxide microinjected into the region of the dorsal raphe nucleus eliminates the interference with escape responding produced by inescapable shock whether administered before inescapable shock or escape testing. Behav Neurosci 108:121-130.

Maier SF, Grahn RE, Watkins LR (1995a) 8-OH-DPAT microinjected in the region of the dorsal raphe nucleus blocks and reverses the enhancement of fear conditioning and interference with escape produced by exposure to inescapable shock. Behav Neurosci 109:404-412.

Maier SF, Busch CR, Maswood S, Grahn RE, Watkins LR (1995b) The dorsal raphe nucleus is a site of action mediating the behavioral effects of the benzodiazepine receptor inverse agonist DMCM. Behav Neurosci 109: 759-766.

Mansbach RS, Brooks EN, Chen YL (1997) Antidepressant-like effects of
CP-154,526, a selective CRF1 receptor antagonist. Eur J Pharmacol 323:21-26.

Martinez V, Barquist E, Rivier J, Tache Y (1998) Central CRF inhibits gastric emptying of a nutrient solid meal in rats: the role of CRF2 receptors. Am J Physiol 274:G965-G970.

Maswood S, Barter JE, Watkins LR, Maier SF (1998) Exposure to inescapable but not escapable shock increases extracellular levels of 5-HT in the dorsal raphe nucleus of the rat. Brain Res 783:115-120.

Paxinos G, Watson C (1986) The rat brain in stereotaxic coordinates, Ed 2. San Diego: Academic.

Pelleymounter MA, Joppa M, Carmouche M, Cullen MJ, Brown B, Murphy B, Grigoriadis DE, Ling N, Foster AC (2000) Role of corticotropinreleasing factor $(\mathrm{CRF})$ receptors in the anorexic syndrome induced by CRF. J Pharmacol Exp Ther 293:799-806.

Porsolt RD, Anton G, Blavet N, Jalfre M (1978) Behavioural despair in rats: a new model sensitive to antidepressant treatments. Eur J Pharmacol 47:379-391.

Price ML, Lucki I (2001) Regulation of serotonin release in the lateral septum and striatum by corticotropin-releasing factor. J Neurosci 21:2833-2841.

Price ML, Curtis AL, Kirby LG, Valentino RJ, Lucki I (1998) Effects of corticotropin-releasing factor on brain serotonergic activity. Neuropsychopharmacology 18:492-502.

Reyes TM, Lewis K, Perrin MH, Kunitake KS, Vaughan J, Arias CA, Hogenesch JB, Gulyas J, Rivier J, Vale WW, Sawchenko PE (2001) Urocortin II: a member of the corticotropin-releasing factor (CRF) neuropeptide family that is selectively bound by type 2 CRF receptors. Proc Natl Acad Sci USA 98:2843-2848.

Ronan PJ, Kramer GL, Kram ML, Petty F (2000) CRF in the learned helplessness animal model of depression: acute and prior administration of CRF causes escape deficits in rats similar to those induced by inescapable stress. Soc Neurosci Abstr 26:2266.

Sakanaka M, Shibasaki T, Lederis K (1986) Distribution and efferent projections of corticotropin-releasing factor-like immunoreactivity in the rat amygdaloid complex. Brain Res 382:213-238.

Sherman AD, Allers GL, Petty F, Henn FA (1979) A neuropharmacologicallyrelevant animal model of depression. Neuropharmacology 18:891-893.

Short KR, Maier SF (1993) Stressor controllability, social interaction, and benzodiazepine systems. Pharmacol Biochem Behav 45:827-835.

Swanson LW, Sawchenko PE, Rivier J, Vale WW (1983) Organization of ovine corticotropin-releasing factor immunoreactive cells and fibers in the rat brain: an immunohistochemical study. Neuroendocrinology 36:165-186.

Takahashi LK, Ho SP, Livanov V, Graciani N, Arneric SP (2001) Antagonism of CRF (2) receptors produces anxiolytic behavior in animal models of anxiety. Brain Res 902:135-142.

Takamori K, Kawashima N, Chaki S, Nakazato A, Kameo K (2001) Involvement of corticotropin-releasing factor subtype 1 receptor in the acquisition phase of learned helplessness in rats. Life Sci 69:1241-1248.

Valdez GR, Inoue K, Koob GF, Rivier J, Vale W, Zorrilla EP (2002) Human urocortin II: mild locomotor suppressive and delayed anxiolytic-like effects of a novel corticotropin-releasing factor related peptide. Brain Res 943:142-150.

Vale W, Spiess J, Rivier C, Rivier J (1981) Characterization of a 41-residue ovine hypothalamic peptide that stimulates secretion of corticotropin and $\beta$-endorphin. Science 213:1394-1397.

Van Pett K, Viau V, Bittencourt JC, Chan RK, Li HY, Arias C, Prins GS, Perrin M, Vale W, Sawchenko PE (2000) Distribution of mRNAs encoding CRF receptors in brain and pituitary of rat and mouse. J Comp Neurol 428:191-212.

Weiss JM, Goodman PA, Losito BA, Corrigan S, Charry JM, Bailey WH (1981) Behavioral depression produced by an uncontrollable stressor: relationship to norepinephrine, dopamine, and serotonin levels in various regions of rat brain. Brain Res Brain Res Rev 3:167-205. 